\title{
Education for Employability in Nigeria: Stakeholders' Assessment of Missing Gaps in the Current Schools Curricula
}

\author{
Babatunde Adeniyi Adeyemi ${ }^{1 *}$, Dr. (Mrs) Beatrice Bunmi Adeyemi ${ }^{2}$, Miss Ibukun Diadem Adeyemi ${ }^{3}$ \\ ${ }^{1}$ Professor, Institute of Education, Obafemi Awolowo University, Ile-Ife, Osun State, Nigeria \\ ${ }^{2}$ General and Entrepreneurial Studies Unit, Olusegun Agagu University of Science and Technology, Okitipupa, Ondo State, Nigeria \\ ${ }^{3}$ Department of Agricultural Economics, Obafemi Awolowo University, Ile-Ife, Osun State, Nigeria
}

Article History

Received: 04.10 .2020

Accepted: 22.10 .2020

Published: 24.03.2021

Journal homepage:

https://www.easpublisher.com

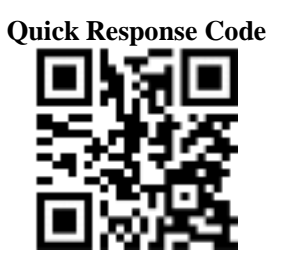

Abstract: The study investigated the stakeholders' perceived adequacy of current school curricula in meeting employability needs of the undergraduates. It equally assessed the stakeholders' position on what can be done on current schools' curricula in order to meet the prevailing employability needs of the undergraduates. It further determined the stakeholders' perceived employability skills needed by the undergraduates and finally examined the difference in students' and lecturers' perceived adequacy of current school curricula in meeting employability needs of the undergraduates. The study employed survey research design and the sample size consisted of 60 lecturers and 600 students purposively selected from five faculties in Obafemi Awolowo University in Ile-Ife, Osun State, Nigeria. An instrument comprising of four sections was developed by the investigators to elicit information from the respondents. The instrument was validated before use using Cronbach's alpha and yielded 0.78. Three research questions and one hypothesis emanated from the study. The results among others showed that majority of the students had low perceived adequacy of current school curricula in meeting employability needs of undergraduates $(45.0 \%)$ while majority of the lecturers had moderate perceived adequacy of current school curricula in meeting employability needs of undergraduates $(61.7 \%)$. Also, there was a significant difference in students and lecturers perceived adequacy of current school curricula in meeting employability needs of the undergraduates $(t=-3.343 ; \mathrm{p}<0.05)$. The study recommended the need for provision of adequate educational facilities as well as improved funding in tertiary institutions in Nigeria.

Keywords: Assessment, Employability, School Curricula, Tertiary Institutions

Copyright ( 12021 The Author(s): This is an open-access article distributed under the terms of the Creative Commons Attribution 4.0 International License (CC BY-NC 4.0) which permits unrestricted use, distribution, and reproduction in any medium for non-commercial use provided the original author and source are credited.

\section{INTRODUCTION}

Education is vital in empowering students and people to acquire skills academically and vocationally for national development. The Federal Government in a bid to emphasize the importance of education and the development of students' employability competence for national development indicates in Section 8 of the National Policy on Education the objectives of tertiary institutions. These are to: (a) contribute to national development through high level relevant training; (b) develop and inculcate proper values for the survival of the individual and society; (c) develop the intellectual capacity of individuals to understand and appreciate their local and external environments; and (d) acquire both physical and intellectual skills which will enable individuals to be self-reliant and useful members of the society. Oliver [1], Yorke and Knights [2], as cited by Pitan [3], define employability to mean what students and graduates can discern, acquire, adapt and continually use to enhance the skills, understanding and personal attributes that make them more likely to find and create meaningful paid and unpaid work that benefits themselves, the workforce, the community and the economy. Considering the economic situation of today's world, one of the major challenges affecting it is unemployment. News abounds of unemployment figure arising daily with unavailable jobs, companies down-sizing and different austerity measures in many countries. Thousands of graduates are turned out from tertiary institutions yearly, instead of being provided with jobs, majority of them pick up jobs that do not commensurate their certificates. According to Sofoluwe and Etejere [4], in Adedeji [5] the tertiary scholastic level has attracted various reactions on the basis that the kind of education provided has not been able to provide solution to the problems of the country as a developing country. These problems include poverty, corruption, unemployment and mismanagement of resources.

The terrible consequence of unemployment among the teeming unemployed graduates cannot be explained; in fact this is evident in the many crimes perpetrated by some of these youths. This invariably results and tantamount to a monumental waste of invaluable manpower that could have been used 
judiciously for societal and national development. This presents the need for the government at various levels to see the importance of providing a curriculum that will address the issue of unemployment by providing the necessary skills students need at their undergraduate level. The Federal Government of Nigeria, in collaboration with agencies such as National Directorate of Employment (NDE) and National Poverty Eradication Programme (NAPEP) among others has taken some steps to alleviate the issue of joblessness [5].

The governments have made concerted efforts at creation of jobs and alleviate poverty; however, there is no way these efforts can completely eradicate the problem of joblessness. Economists have identified entrepreneurship as a possible way out of the problems. This is to develop in the students the awareness of the occupational world and the need to acquire the needed skills. Entrepreneurship as a compulsory course should be included in tertiary institution curricula. A student who has the desire to pursue a particular career and profession in the higher institution should begin to plan towards becoming an entrepreneur. Planning for this will assist such individual to be proactive in being a job provider rather than a job recipient. Entrepreneurship is introduced in some higher institutions of learning as Special Electives while there is no provision for it in other universities. Including entrepreneurship as a compulsory course in higher institution curricula will save the students the trauma and frustration of wandering about looking for job that may not be available.

Bilgin, Rowe, \& Clark [6], as cited in Rowe and Zegwaard [7], indicate that the experience of workintegrated learning alone does not guarantee employability outcomes for students and graduates. For effectiveness, such experiences should be embedded in the curriculum and supported by pedagogical strategies throughout a programme to maximize learning opportunities. This indicates that including courses in the higher education curricula will prepare undergraduate students for the labour market.

Mason [8] indicates that recent evidence of employer difficulties in recruiting graduates shows concerns about quality shortcomings in some graduate job applicants- especially, lack of practical work experience and commercial understanding. Most employers prefer workers who are problem solvers and that can take initiatives easily. These are people who are empowered to take good decisions for the advancement of the business.
Considering the need to enhance graduates employability in Nigeria, appropriate steps should be taken to develop a school curriculum that will encompass the acquisition of fundamental employability skills. In the view of Pitan [3], the concept of employability transcends the possession of both academic and generic skills; it further implies the utilization and development of such assets and is a lifelong process.

\section{Statement of Problem}

This paper addresses the assessment of stakeholders of the missing gap in the current school curriculum in terms of providing education that will enhance graduates employability in Nigeria. The unemployment experienced in Nigeria especially by young graduates is alarming. Consequently, some of them in order to while away unprofitable engagements took to lesser paid jobs. However, if they have been exposed to vigorous entrepreneurial skills in their undergraduates days they would have engaged in or develop innovative businesses that would tackle the challenge of unemployment. Henry Ford who was a mechanic apprentice used his leisure-hour experiments with automobiles judiciously and eventually became Ford Motor Company. This study proposes the need to include courses in the current school curricula that are tailored towards education for employability.

\section{Purpose of the Study}

The main purpose of this study was to investigate the missing gap in the current school curricula vis-à-vis lecturers and students perspectives in Obafemi Awolowo University, Ile-Ife, Nigeria. However, the specific purposes of the study were to:

1. Investigate the stakeholders' perceived adequacy of current school curricula in meeting employability needs of the undergraduates;

2. Assess stakeholders' position on what can be done on current schools' curricula in order to meet the prevailing employability challenges;

3. Determine the stakeholders' perceived employability skills needed by the undergraduates; and

4. Examine the difference in students' and lecturers perceived adequacy of current school curricula in meeting employability needs of the undergraduates.

\section{Research Questions}

1. How do stakeholders perceive adequacy of current school curricula in meeting employability needs of the undergraduates? 
2. What is the stakeholders' position on what can be done on current schools curricula in order to meet the prevailing employability challenges?

3. What are the stakeholders' perceived employability skills needed by the undergraduates?

\section{HYPOTHESIS}

There is no significant difference in students and lecturers perceived adequacy of current school curricula in meeting employability needs of the undergraduates.

\section{Methodology}

The study adopted the survey research design. The population consisted of all the lecturers and students in Obafemi Awolowo University, Ile-Ife, Osun State, Nigeria. Multistage sampling procedure was employed in selecting 60 lecturers and 600 students from five faculties (Administration, Agriculture, Arts, Education and Social Sciences) out of thirteen faculties. The purposive selection was based on the fact that these disciplines are tailored toward humanity. Accidental sampling techniques was employed in selecting 12 lecturers in each of the selected faculties while simple random sampling technique was employed in selecting 120 students form either 400 level or 500 level in each of the selected faculties. The investigators developed an instrument titled: Education for Employability Questionnaire (EEQ). It has four sections. Section A elicited demographic information from the respondents while Section B had fifteen items on perceived adequacy of current school curricula in which the respondents are expected to tick as appropriate from SA $=$ Strongly Agree (4) points, A = Agree (3) points, $\mathrm{D}=$ Disagree (2) points and SD = Strongly Disagree (1) with the maximum score of 60 points while the least score is 15 points. Section $\mathrm{C}$ had six items on what could be done to ravage the current school curricula in which the respondents are equally expected to tick as appropriate from SA = Strongly Agree (4) points, $\mathrm{A}=$
Agree (3) points, $\mathrm{D}=$ Disagree (2) points and $\mathrm{SD}=$ Strongly Disagree (1) point with the maximum score of 24 points while the least score is 6 points. Section D had three items on perceived employability skills needed by undergraduates where the respondents are equally expected to tick as appropriate from $\mathrm{SA}=$ Strongly Agree (4) points, A = Agree (3) points, D = Disagree (2) points and $\mathrm{SD}=$ Strongly Disagree (1) point with the maximum score of 12 points while the least score is 3 points. In order to ensure the validity of the instrument, copies of the draft of the instrument were given to experts in Test and Measurement, English Language and colleagues for their comments on the face and content validity. Based on their comments and corrections, corrected copy was tested for reliability. Copies of the questionnaire were administered in another university using 30 lecturers and 90 students. The Cronbach's alpha was employed and the coefficient of 0.78 was obtained. Data collected were analysed using frequency counts, simple percentages, mean, standard deviation and t-test statistics.

\section{RESULTS}

Research Question 1: How do stakeholders perceive adequacy of current school curricula in meeting employability needs of the undergraduates?

To answer this research question, students and lecturers' responses to Section B based on the items in the questionnaire as rated by the investigators, were used. The respective scores were summed up to build their adequacy level of current school curricula in meeting employability needs of the undergraduates. The Mean and Standard deviation were 32.25 and 7.708 respectively. Stakeholders' whose scores were below the mean were considered as having low level, those whose scores are between 32.25-39.958 were considered as having moderate level and stakeholders whose score are above 40 were considered as having high level.

Table 1: Perceived Adequacy level of current school Curricula

\begin{tabular}{|l|l|l|l|l|}
\hline Stakeholders & High (\%) & Moderate (\%) & Low (\%) & Total (\%) \\
\hline Students & $93(15.5)$ & $237(39.5)$ & $270(45.0)$ & $600(100.0)$ \\
\hline Lecturers & $11(18.3)$ & $37(61.7)$ & $12(20.0)$ & $60(100.0)$ \\
\hline
\end{tabular}

Table-1 showed that $15.5 \%$ of students had high level, $39.5 \%$ had moderate level, and $45.0 \%$ had low level. Also, $18.3 \%$ of lecturers had high level, $61.7 \%$ had moderate level and $20.0 \%$ had low level. There is an indication from this result that majority of the students that participated in the study had low perceived adequacy of current school curricula in meeting employability needs of undergraduates while majority of the lecturers that participated in the study had moderate perceived adequacy of current school 
Babatunde Adeniyi Adeyemi et al., EAS J Humanit Cult Stud; Vol-3: Iss-2 (Mar-Apr, 2021): 97-102

curricula in meeting employability needs of Research Question 2: What is the stakeholders' undergraduates.

position on what can be done on current school Curricula in meeting employability needs of undergraduates?

Table-2: Stakeholders' position on what can be done on current school curricula

\begin{tabular}{|l|l|l|l|l|}
\hline \multirow{2}{*}{ Motivation of qualified lecturers } & Stakeholders & $\mathbf{N}$ & Mean & S.D \\
\hline Curriculum review & Students & 600 & 3.43 & .762 \\
\cline { 2 - 5 } & Lecturers & 60 & 3.52 & .752 \\
\hline \multirow{2}{*}{ Regular and effective university accreditation } & Students & 600 & 3.52 & .342 \\
\cline { 2 - 5 } & Lecturers & 60 & 3.57 & .532 \\
\hline Provision of adequate educational facilities & Students & 600 & 3.70 & .305 \\
\cline { 2 - 5 } & Lecturers & 60 & 3.61 & .465 \\
\hline Improved funding & Students & 600 & 3.74 & .342 \\
\cline { 2 - 5 } & Lecturers & 60 & 3.69 & 1.015. \\
\hline \multirow{2}{*}{$\begin{array}{l}\text { Establishing a workable link between universities and } \\
\text { employers of labour }\end{array}$} & Students & 600 & 3.54 & 1.125 \\
\cline { 2 - 5 } & Lecturers & 60 & 3.70 & .942 \\
\cline { 2 - 5 } & Students & 600 & 3.75 & .876 \\
\cline { 2 - 5 } & Lecturers & 60 & 3.69 & .351 \\
\hline
\end{tabular}

To answer this research question, students and lecturers' responses to Section $\mathrm{C}$ based on the items in the questionnaire as rated by the investigators, were used. From Table-2, stakeholders strongly agreed that it is necessary to motivate qualified lecturers (students, $\mathrm{M}=3.43$, S. $\mathrm{D}=.762$; lecturers, $\mathrm{M}=3.52$, S. $\mathrm{D}=.752$ ), curriculum review (students, $\mathrm{M}=3.52, \mathrm{~S}$. $\mathrm{D}=.342$; lecturers, $\mathrm{M}=3.57$, $\mathrm{S}$. $\mathrm{D}=.532$ ), regular and effective university accreditation (students, $\mathrm{M}=3.70, \mathrm{~S} . \mathrm{D}=.305$; lecturers, $\mathrm{M}=3.61, \mathrm{~S}$. $\mathrm{D}=.465$ ), provision of adequate educational facilities (students, $\mathrm{M}=3.74, \mathrm{~S}$. $\mathrm{D}=.342$; lecturers, $\mathrm{M}=3.69$, S. $\mathrm{D}=1.015$ ). Stakeholders also strongly agreed that there is need for improved funding (students, $\mathrm{M}=3.54$, S. $\mathrm{D}=1.125$; lecturers, $\mathrm{M}=3.70$, S. $\mathrm{D}=.942$ ) and establishment of workable link between universities and employers of labour (students, $M=3.75$, S. $D=.876$; lecturers, $M=3.69$, S. $D=.351$. From the findings above, this clearly indicates what needs to be done on current school curricula in order to meet the prevailing employability challenges.

Research Question 3: What are the stakeholders' perceived employability skills needed by the undergraduates?

Table-3: Stakeholders' perceived employability skills needed by undergraduates

\begin{tabular}{|l|l|l|l|l|}
\hline Employability Skills & Stakeholders & N & Mean & S.D \\
\hline Basic Academic Skills & Students & 600 & 3.57 & 0.500 \\
\cline { 2 - 5 } (Reading, writing, arithmetic) & Lecturers & 60 & 3.60 & 1.947 \\
\hline \multirow{2}{*}{$\begin{array}{l}\text { Higher Order Thinking } \\
\text { (Reasoning, creativity, thinking) }\end{array}$} & Students & 600 & 3.50 & 0.898 \\
\cline { 2 - 5 } & Lecturers & 60 & 3.70 & 1.608 \\
\hline $\begin{array}{l}\text { Personal Qualities } \\
\text { (Self-control, team control) }\end{array}$ & Students & 600 & 3.68 & 1.212 \\
\cline { 2 - 5 } & Lecturers & 60 & 3.63 & 1.015 \\
\hline
\end{tabular}

To answer this research question, students and lecturers' responses to Section D based on the items in the questionnaire as rated by the investigators, were used. Table 3 indicates the perceived employability skills of students and lecturers needed by undergraduates. It can therefore be deduced that employability skills needed by undergraduates pertinent to both students and lecturers were: basic academic skills (students, $\mathrm{M}=3.57, \mathrm{~S}$. $\mathrm{D}=0.500$; lecturers, $\mathrm{M}=3.60$, S. $\mathrm{D}=1.947$ ), higher order thinking (students,
$\mathrm{M}=3.50$, S. $\mathrm{D}=0.898$; lecturers, $\mathrm{M}=3.70, \mathrm{~S} . \mathrm{D}=1.608$ ), and personal qualities (students, $\mathrm{M}=3.68, \mathrm{~S} . \mathrm{D}=1.212$; lecturers, $\mathrm{M}=3.63, \mathrm{~S} . \mathrm{D}=1.015$ ).

\section{Hypothesis}

There is no significant difference in students and lecturers perceived adequacy of current school curricula in meeting employability needs of the undergraduates. 
Table 4: t-test Summary Table showing the difference in stakeholders perceived adequacy of current school curricula

\begin{tabular}{|l|l|l|l|l|l|l|}
\hline Stakeholders & N & Mean & Std. Deviation & Df & t & P \\
\hline Students & 600 & 31.97 & 7.741 & 75.195 & -3.343 & .001 \\
\hline Lecturers & 60 & 35.08 & 6.793 & & & \\
\hline
\end{tabular}

Table-4 shows the difference in students and lecturers perceived adequacy of current school curricula in meeting employability needs of undergraduates. It can be seen from the table that the p-value is less than 0.05 , it can therefore be concluded that there is a significant difference in students and lecturers perceived adequacy of current school curricula in meeting employability needs of the undergraduates $(\mathrm{p}=0.001)$.

\section{DisCUSSION OF FINDINGS}

From this study, the result revealed that majority of the students who involved in the study had low perceived adequacy of the current school curricula in meeting employability needs of undergraduates while majority of the lecturers involved in the study had moderate perceived adequacy of current school curricula in meeting employability needs of undergraduates. This shows that most of the students and lecturers pointed out that the current school curricula fall short of meeting with the employability needs of undergraduates. This supports the findings of Oladipo, Adeosun and Oni [9]; Bamiro, Adedeji and Pitan [10] who stated that the Nigerian university curriculum, just as the curricula of many other developing countries, has been criticized for not only lacking in content and quality; but also for being largely theoretical and overloaded, obsolete and disconnected from the labour market and therefore, inadequate to attend to the needs of the $21^{\text {st }}$ century students.

Oladipo et al., [9], Asiyai [11], as cited by Pitan [3] further stressed that Nigerian universities are plagued by an unreliable electricity supply, grossly deficient and inadequate hostels and a lack of exposure to the latest computer software. The interactions with some undergraduates affirmed less percentage of students who are exposed to career education skills. Knight and Yorke [12], as cited by Pitan [3] indicated that the university's contribution to student employability in addition to its performance in general has much to do with the quality of its career service.

The result of the study indicated that qualified lecturers should be motivated in meeting the employability needs of undergraduates and there must be curriculum review with a view to including career education activities. Moreover, regular and effective university accreditation, improved fund and establishing a workable link between universities and employers of labours should be put into consideration. Pitan [3] affirmed this assertion by stressing that in spite of the significance of collaboration between universities and employers of graduates, the role of employers in contributing to curriculum design and graduate recruitment has not been encouraging. In the view of Robinson [13] as cited by Onyeike and Onyeagbako [14], employability skills are basic skills necessary for getting, keeping and doing well on a job. This indicates that adequate provisions of facilities, proper review of curriculum with consideration of undergraduate needs should be considered.

The result obtained from the stakeholders' perceived employability skills needed by undergraduates include basic academic skills, higher order thinking and personal qualities. Philips Consulting 2014, as cited by Adedeji [15] maintained that graduates underestimated the importance of the ability to think critically and analytically as they saw analytical skill as insignificant skills. Consequently, employers of labour expressed a high level of dissatisfaction with this skill along with graduates' inability to work effectively on their own. Students need a number of skills and qualities, apart from their academic or professional qualifications to be successful.

\section{CONCLUSION}

Based on the findings of this study, it is concluded that undergraduate students had low perceived adequacy of current school curricula in meeting employability needs of undergraduates while majority of the lecturers that participated in the study had moderate perceived adequacy of current school curricula in meeting employability needs of undergraduates. Not only that, the employability skills needed by undergraduates as pointed by both students and lecturers include basic academic skills, higher order thinking and personal qualities.

\section{RECOMMENDATIONS}

There is need for provision of adequate educational facilities as well as improved funding in 
tertiary institutions in Nigeria together with establishing a workable link between universities and employers of labour. Moreover, there should be a review of the curricula of higher institutions to include career activities to prepare the students in case of nonavailability of white collar jobs.

\section{REFERENCES}

1. Oliver, B. (2015). Redefining graduate employability and work-integrated learning. Journal of Teaching and Learning for Graduate Employability, 6(1):56-65.

2. Yorke, M. \& Knight, P. T. (2006). Embedding Employability into the Curriculum. Learning and Employability Series One. York: Higher Education Academy.

3. Pitan, O. S. (2016). Towards enhancing university graduate employability in Nigeria. Journal of Sociology.

4. Sofoluwe, A. O., \& Etejere, P. (2011). Tertiary education and entrepreneurship in Nigeria. Journal of Research in Education. 1(1), 148-156.

5. Adedeji, I. S. (2017). Labour market requirements and university graduate employability skills competence in North-West, Nigeria. International Journal of Education Management, 15(1):1-20

6. Bilgin, A. A., Rowe, A. D., \& Clark, L. (2017). Academic workload implications of assessing student learning in work-integrated learning. AsiaPacific Journal of Cooperative Education (Special Issue), 18(2):165-181.

7. Rowe, A. D., \& Zegwaard, K. E. (2017). Developing graduate employability skills and attributes: Curriculum enhancement through workintegrated learning. Asia-Pacific Journal of
Cooperative Education. Special Issue, 18(2):8799.

8. Mason, G. (2001). The mix of graduate and intermediate-level skills in Britain: What should the balance be? Journal of Education abd Work, 14(1), 5-27.

9. Oladipo, A., \& Adeosun, O., (2009). Quality Assurance and Sustainable University Education in Nigeria. From http://aadcice.hiroshimau.ac.jp/e/publications/sosh 041-09.pdf. (Retrieved on 12 October 2015).

10. Bamiro, O., Adedeji, O., \& Pitan, O. (2013). Transforming Nigeria economy through sustainable financing of higher education in: $\mathrm{O}$. Oni (Ed.): Challenges and Prospects in Africa Education System. USA and Canada: Trafford Pubiishing INC, pp 283-395

11. Asiyai, R. I. (2013). Challenges of quality in higher education in Nigeria in the $21 \mathrm{st}$ century. International Journal of Educational Planning \& Administration, 3(2), 159-172.

12. Knight P. T., \& Yorke, M. (2003). Employability and good learning in higher education. Teaching in Higher Education. 8(1): 3-16. DOI: 10. 1080/135625 1032000052294.

13. Robinson, J. P. (2000). What are employability skills? The workplace 3(3) 1-3 September 2000 (ACES, 2000).

14. Onyeike, V. C., \& Onyeagbako, S. O. (2017). Enhancing employability through university education: The role of National University Commission (NUC), Global Journal of Educational Research, 13:109-115.

15. Adedeji, O. (2014). Global climate change. Journal of Geoscience and Environment Protection, 2(02), 114.

Cite This Article: Babatunde Adeniyi Adeyemi et al (2021). Education for Employability in Nigeria: Stakeholders' Assessment of Missing Gaps in the Current Schools Curricula. EAS J Humanit Cult Stud, 3(2), 97-102. 